\title{
The Analysis of Mathematics Curriculum Materials: Addition and Subtraction in Grade 31)
}

\author{
Gooyeon Kim(Assistant Professor, Sogang University)* \\ $\ll$ SUMMARY
}

This study aims to examine how Korean elementary mathematics curriculum materials support teachers for successful implementation of reform ideas of the 7th National Curriculum and 2007 National Curriculum Amendment (3-1 only). I analyzed the curriculum materials in grade 3 with a framework considering: a) instructional tasks for students to examine cognitive demands of instructional tasks designed for students, b) teacher materials in terms of whether the curriculum developers' rationales are visible, and c) teacher materials in terms of whether the materials help teachers anticipate students' responses. The findings suggest that: a) instructional tasks in the textbook focus on understanding and use of procedures in adding and subtracting 3-digit whole numbers; and b) the Teacher's Guides seem not transparent and to not help teachers anticipate students' responses in teaching addition and subtraction with whole numbers.

Key words : reform-oriented mathematics curriculum, textbook and teacher's guides, curriculum material analysis, cognitive demand, addition and subtraction in grade 3, teacher learning opportunities

\section{I . Introduction}

A curriculum is an organized plan for instruction "that details what mathematics students need to know, how students are to achieve the identified curricular goals, what teachers are to do to help students develop their mathematical knowledge, and the context in which learning and

1) This work was supported by the Sogang University Research Grant of 2009.

* First Author and Corresponding Author, gokim@sogang.ac.kr 
teaching occur" (National Council of Teachers of Mathematics, 1989, p. 1). Accordingly, mathematics curriculum materials detail what and how to teach mathematical ideas in mathematics classrooms. Thus, mathematics curriculum materials have been considered as a crucial medium to convey new ideas about teaching and learning and to implement such ideas in classrooms.

Curriculum materials have been viewed as educative materials for teacher learning (Ball \& Cohen, 1996; Davis \& Krajcik, 2005). Teachers with such materials are expected to teach mathematical ideas conceptually in meaningful situations with authentic activities in order to facilitate students learning mathematics. To use the curriculum materials well requires the teachers to transform classroom implementation fundamentally.

This paper aims to examine Korean elementary mathematics curriculum materials in terms of teacher-curriculum material relationships. For the purpose of exploring the teacher-curriculum material relationships, this study analyzes elementary curriculum materials such as Teacher's Guides and textbooks designed for students in terms of how the curriculum materials are designed to support teacher learning and the adoption of new ideas suggested, explicitly and implicitly, in the reform-oriented curriculum materials developed as a result of the 7th National Curriculum reform and 2007 National Curriculum Amendment in Korea.

I begin with an overview of research studies on curriculum materials and then describe a framework for analyzing curriculum materials. I then illustrate the process of data collection and analysis. Finally, I present the findings from the analysis and discuss implications for further study and curriculum development.

\section{II . Theoretical Framework}

Teachers read, interpret, and implement curriculum materials that are selected for their classroom instruction (Remillard, 1999, 2005; Remillard \& Bryans, 2004; Stein, Remillard \& Smith, 2007). In so doing, teachers develop and integrate their knowledge about teaching, learning, and content of mathematics (Collopy, 2003; Davis \& Krajcik, 2005; Llyod, 1999, 2008). This leads to focus on the teacher portion of curriculum materials to investigate the role of curriculum materials in promoting teacher learning (Ball \& Cohen, 1996; Collopy, 2003; Davis \& Krajcik, 2005; Remillard, 2000; Stein \& Kim, 2009).

The analysis of curriculum materials should focus on both base programs and the teacher 
materials by distinguishing the base curriculum materials from the materials designed directly for teachers (Stein \& Kim, 2009). Herein, base programs refer to "the portion of the materials that is directly pitched to students and their learning" (p. 41) and teacher materials "the parts intended to guide teachers as they use the materials" (p. 41). Research studies on curriculum typically have been focused on only the base programs (Freeman \& Porter, 1989; Tarr, Chavez, R. Reys \& B. Reys, 2006). Examining both base programs and teacher materials enables us to better understand both the nature of tasks for students and of student thinking in the base programs, and teacher learning demand in the teacher materials according to the level of student thinking.

By adopting the guidelines in designing educative curriculum materials developed by Davis and Krajcik (2005), Stein and Kim (2009) suggest a framework for analyzing mathematics curriculum materials that is based on a viewpoint of teacher-curriculum material relationship. The teacher-curriculum material relationship presumes teachers essentially interact with curriculum materials. Teacher-curriculum material relationship includes the active participation by both teacher and the curriculum material. This leads to concentrate attention toward particular features of the curriculum materials and teachers' interpretation of those features. Thus, the framework for the analysis of curriculum materials entails the following: a) cognitive demands of instructional tasks; b) whether curriculum developers' underlying rationales for a particular task are visible; and c) whether the curriculum materials support teachers to learn how to anticipate students' responses.

The framework for analysis of the curriculum materials, specifically, examines cognitive demands on tasks in the base programs, which consist of instructional tasks for students. The instructional tasks vary with regard to the level of cognitive demand on students (Stein, Grover, \& Henningsen, 1996). In particular, reform-oriented or Standards-based mathematics curriculum materials contain more high-level cognitive demands tasks than low-level in that those programs requires students to develop conceptual knowledge and to focus on the processes utilized in mathematics such as problems solving, reasoning, connections, communication, and representation (Stein \& Kim, 2009). The findings about the cognitive demand of the instructional tasks from the analyses of two reform-oriented elementary mathematics programs that are widely used in the United States, Everyday Mathematics and Investigations in Number, Data, and Space, suggest that most of the tasks from both programs are high-level in terms of cognitive demand on students. The two programs, however, are noticeably different as Everyday Mathematics includes more procedures with connections (PWC) tasks while Investigations includes more doing mathematics (DM) tasks (Stein \& Kim, 2009). According to the task analysis guide (Stein, Smith, Heningsen \& Silver, 2000), doing mathematics (DM) tasks refer to tasks that are open-ended with limited 
guidance for students and thus, require complex and non-algorithmic thinking such as problem solving, exploration, examination, etc. to successfully complete given tasks. Considered with DM tasks as high-level cognitive demand, procedures with connections (PWC) tasks focus students' attention on the use of procedures for the purposes of developing deeper levels of understanding of mathematical concepts and ideas; PWC tasks suggest pathways or procedures to follow, which make connections to meaning, underlying concepts, or understanding, and further, those procedures cannot be followed mindlessly.

The task analysis framework also suggests low-level demands of mathematical tasks, memorization and procedures without connections (PNC) tasks. Memorization tasks involve reproducing facts, rules, formulae, or definitions by relying on memory. Therefore, such tasks have no connections to the concepts or meaning of the fact, rules, formulae, or definitions. Procedures without connections tasks are algorithmic and require the use of particular procedures or algorithms and thus, focus on producing correct answers rather than developing mathematical understanding. Similar to memorization tasks, PNC tasks have no connections to the concepts or meaning of the procedures and require no explanations, or explanations focusing only on describing the procedures that were used.

Transparency was identified and used for analyzing teacher materials; it refers to "the visibility of the curriculum developers' rationales for specific instructional tasks or particular learning pathways found in the base program" (Stein \& Kim, 2009, p. 46). Curriculum developers design tasks in which students encounter particular contexts for mathematical concepts and procedural skills. The developers' rationales for the particular mathematical tasks are often implicit to the consumer of the curriculum. In other words, teachers' materials typically include step-by-step directions, sets of mathematical problems to present to students, lists of questions to ask, and answers the mathematical problems presented, with little information about the underlying assumptions or perspectives for the design of mathematical tasks (Remillard, 2000). However, curriculum materials must "speak to teachers about the mathematical ideas underlying the tasks" (Remillard, 2000, p. 347). That is, making developers' rationales visible, or transparent, in curriculum materials, (Stein \& Kim, 2009), support teachers to "see connections among suggested activities in the program, their own understanding of mathematics, and what they believe is important to learn, thereby moving them away from teaching a list of unconnected, isolated topics and toward teaching mathematical concepts and ideas" (p. 45).

Curriculum materials can help teachers learn how to anticipate what students may think and do in performing mathematical tasks (Ball \& Cohen, 1996; Collopy, 2003; Davis \& Krajcik, 2005; 
Remillard, 2000; Stein \& Kim, 2009). Anticipating students' responses is critical in that students' mathematical thinking and ways of understanding should be central to mathematics instruction (National Council of Teachers of Mathematics, 1989, 1991) and teachers face many challenges in managing such instructional activities (Ball, 2001; Boston \& Smith, 2009; Cohen, 1990; Collopy, 2003; Lloyd, 1999; Remillard, 2004; Stein, Grove \& Henningsen, 1996). In addition,

\footnotetext{
anticipating students' responses involves developing considered expectations about how students might interpret a problem, the array of strategies-both correct and incorrectthey might use to tackle it, and how those strategies and interpretations might relate to the mathematical concepts, procedures, and practices that the teacher would like her students to learn (Stein \& Kim, 2009, p. 45)
}

By using the framework for analysis of curriculum materials, Stein \& $\operatorname{Kim}(2006,2009)$ analyzed two reform-oriented curriculum materials in the elementary level, Everyday Mathematics and Investigations in Number, Data, and Space (Investigations), which are widely used in the U.S. They found both curriculum materials were comprised of high-level tasks; however, the two were significantly different. That is, Everyday Mathematics had more PWC tasks (79 percent) than DM tasks (12 percent), whereas Investigations was mainly composed of DM tasks (89 percent) and the rest were PWC (11 percent) tasks. Similarly, Son and Send (2010) found in their comparative study that both Everyday Mathematics and the 7th National Curriculum predominantly comprised of procedural knowledge type of problems in terms of cognitive expectation. In addition, the findings showed that the two curriculum materials were different in terms of transparency and anticipation of students' responses. Investigations were judged to be more transparent (80 percent) than Everyday Mathematics (21 percent). "The typical Everyday Mathematics lesson tended to tell teachers what to do, but not why they were doing it" (p. 48). Regarding the extent to which the curriculum materials provided teachers with support in anticipating students' responses, it is suggested that among Everyday Mathematics lessons, 30 percent incorporated examples of students' work or mathematical thinking. In contrast, 91 percent of Investigations lessons included "student responses, student work, examples of students' difficulties or confusions, students' strategies for solving problems, or explanations of how students might make sense of mathematical ideas and interpret problems" (p. 48).

This study examines how Korean elementary mathematics curricular materials support teachers for successful implementation of reform ideas of curricula. For this purpose, I adopt the framework for analyzing curriculum materials and analyze: a) instructional tasks for students to 
examine cognitive demand on those tasks, b) teacher materials in terms of whether the curriculum developers' rationales are visible, referred as transparency, and c) teacher materials in terms of whether the materials help teachers anticipate students' responses to instructional activities.

In the following sections, I illustrate the process of data collection and analysis in detail and the findings from the analysis. Finally, I summarize the study and discuss the findings in broader contexts and implications of the study.

\section{III . Methods}

I collected Korean mathematic curriculum materials produced from the 7th National Curriculum that aims to promote students' conceptual and procedural understanding. The significant ideas and underlying rationales for the development of the national mathematics curriculum aligns with NCTM Standards (1989, 1991, 2000). Teacher's guides in fact explicitly describe the principles and standards of NCTM such as problem solving, conceptual knowledge, communication, reasoning and proof, positive disposition towards mathematics, etc. In addition, 2007 National Curriculum Amendment as an effort to advance the 7th National Curriculum generated a new set of mathematics curriculum materials recently. The new curriculum materials have been implemented in grade 3 this year, but only for first academic semester (Mathematics 3-1) at this time, which was also gathered for this study.

The curriculum materials collected for this study include textbooks, workbooks, and teachers' guides produced from both national curriculum reform-the 7th National Curriculum \& 2007 National Curriculum Amendment. In particular, among other materials for teachers, I only analyzed Teacher's Guides as many teachers tend to use teachers' guides (Stein, Kim \& Seely, 2006). For this study, I selected chapters of addition and subtraction for grade 3 because the strand of number and operations is the focal point to elementary grades and the concept of adding and subtracting whole numbers under the strand is critical for elementary students to develop number sense.

I coded instructional tasks in the textbooks and workbook for grade 3 that were developed from the 7th National Curriculum and 2007 National Curriculum Amendment in order to identify cognitive demands on those tasks for students' mathematical learning. Before I began coding, I divided activities in the textbook into tasks and numbered them. A mathematical task in this study refers to a purposefully contextualized activity or a set of such activity (NCTM, 1995) that 
aims to focus students' attention on a particular mathematical idea (Stein, Grover \& Henningsen, 1996). Then, I assigned a code to each task according to the Task Analysis Guide (Stein, Smith, Henningsen \& Silver, 2000, p. 16), focusing on memorization; procedures without connections to concepts, meaning or understanding (PNC); procedures with connections to concepts, meaning or understanding (PWC); and doing mathematics. Further, I sought for a peer review about the coding with the levels of cognitive demand and consulted a mathematics educator about the cognitive demand of instructional tasks in both kinds of curriculum materials in order to increase the reliability of the analysis. The mathematics educator and I agreed on all the codes of cognitive demands on instructional tasks except two tasks in the 7th curriculum. Then, we discussed about the issue and reached a consensus code.

I investigated the Teacher's Guides in terms of transparency, whether the rationales for a particular task design are given in the teachers' materials. I considered transparent materials as including "explanations for why a particular task or route through a teaching-and-learning territory was selected" and explanations of "the mathematical ideas related to the task" (Stein \& Kim, 2009, p. 47). Then, I examined the teachers' material for whether it is designed to provide teachers with examples of actual student work including students' invented strategies, drawings, or representation, and students' possible interpretation, approaches, questions, difficulties, confusions, or common errors.

\section{IV . Findings}

First, the findings from the task analysis on cognitive demands show that instructional tasks in the curriculum materials from the 7th National Curriculum Reform and from 2007 National Curriculum Amendment for elementary students in grade 3 focus on understanding and use of procedures in adding and subtracting 3-digit whole numbers. As shown in $\langle$ Table 1$\rangle$ and $\langle$ Table 2), 61 percent (14 out of 23 tasks) of tasks in the 7th curriculum were high-level and 64 percent (9 out of 14 tasks) of tasks in the curriculum materials developed by 2007 National Curriculum Amendment were low-level with regard to cognitive demand.

Among the high-level tasks, however, there are no tasks requiring complex and non-algorithmic thinking-doing mathematics tasks - and all of the tasks focus on the use of procedures for understanding of computation of three- or four-digit whole numbers. For instance, a task identified 
as PWC was designed for students to understand the concept of addition of 974 and 468 with base-ten blocks. For the task, the textbook illustrates the following steps:

- Use base-ten blocks and represent 974 and 468 with them.

- How many tens and ones when you add ones in both numbers?

- How many hundreds and tens when you add tens in both numbers?

- How many thousands and hundreds when you add hundreds in both numbers?

- How much would $974+468$ be?

- Why do you think it is? (Ministry of Education, 2001a, p. 20)

〈Table 1〉 Cognitive Demand of Instructional Tasks in Both Curricula

\begin{tabular}{ccc}
\hline & \multicolumn{2}{c}{ Cognitive Demand } \\
\hline \hline \multirow{2}{*}{ The 7 th Curriculum } & Procedures with & $61 \%$ \\
$(23$ tasks $)$ & Connections & $(14 / 23)$ \\
\cline { 2 - 3 } & Procedures without & $39 \%$ \\
& Connections & $(9 / 23)$ \\
\hline \multirow{2}{*}{2007 Amendment } & Procedures with & $36 \%$ \\
(14 tasks) & Connections & $(5 / 14)$ \\
& Procedures without & $64 \%$ \\
& Connections & $(9 / 14)$ \\
\hline
\end{tabular}

$\langle$ Table 2〉 Instructional Tasks and Cognitive Demand

\begin{tabular}{|c|c|c|c|c|c|}
\hline 7th: $3-1$ & $\begin{array}{c}\text { Cognitive } \\
\text { Demand }\end{array}$ & 7th: $3-2$ & $\begin{array}{c}\text { Cognitive } \\
\text { Demand }\end{array}$ & 2007: $3-1$ & $\begin{array}{c}\text { Cognitive } \\
\text { Demand }\end{array}$ \\
\hline Task 1 & PWC & Task 1 & PWC & Task 1 & $\mathrm{PNC}$ \\
\hline Task 2 & PWC & Task 2 & PWC & Task 2 & PNC \\
\hline Task 3 & PWC & Task 3 & $\mathrm{PNC}$ & Task 3 & PWC \\
\hline Task 4 & $\mathrm{PNC}$ & Task 4 & $\mathrm{PNC}$ & Task 4 & PWC \\
\hline Task 5 & PWC & Task 5 & PWC & Task 5 & PNC \\
\hline Task 6 & PWC & Task 6 & PWC & Task 6 & $\mathrm{PNC}$ \\
\hline Task 7 & PWC & Task 7 & $\mathrm{PNC}$ & Task 7 & PWC \\
\hline Task 8 & $\mathrm{PNC}$ & Task 8 & $\mathrm{PNC}$ & Task 8 & PWC \\
\hline Task 9 & PWC & Task 9 & $\mathrm{PNC}$ & Task 9 & $\mathrm{PNC}$ \\
\hline Task 10 & PWC & Task 10 & $\mathrm{PNC}$ & Task 10 & PWC \\
\hline \multirow[t]{4}{*}{ Task 11} & PWC & Task 11 & $\mathrm{PNC}$ & Task 11 & $\mathrm{PNC}$ \\
\hline & & Task 12 & PWC & Task 12 & $\mathrm{PNC}$ \\
\hline & & & & Task 13 & $\mathrm{PNC}$ \\
\hline & & & & Task 14 & PNC \\
\hline
\end{tabular}


As suggested in the textbook, this task involves use of manipulatives-base-ten blocks in this case -in order to develop the concept of adding two numbers. Also, the task requires an explanation of how adding the two numbers is facilitated correctly. In so doing, the task encourages students to pay attention to the use of procedures of adding the two numbers, which corresponds to the steps with the use of base-ten blocks in adding 974 and 468. That is, the steps suggested seems to follow algorithms in adding two numbers in which two numbers are lined up and computed from the ones digit to larger ones as shown in [Figure 1]. Similarly, the following task suggests possible pathways to follow that have close connections to underlying conceptual ideas in adding two numbers as described in [Figure 2].

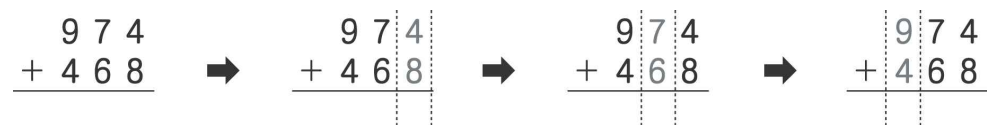

(Figure 1) A pathway suggested to add two 3-digit whole numbers (Ministry of Education of Korea, 2001a, p. 20)
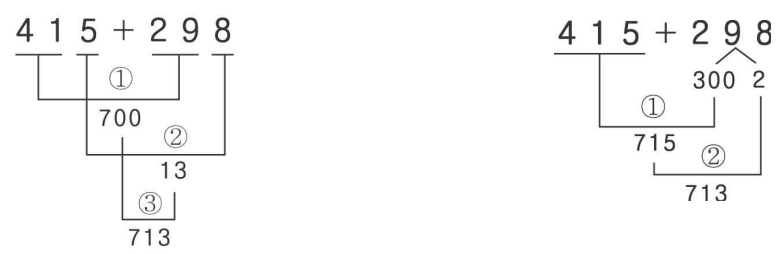

[Figure 2) Possible methods suggested by the task (Ministry of Education of Korea, 2001a, p. 22)

Besides, a task of 2007 curriculum also encourages the students to focus on the use of suggested methods in adding and subtracting two 3-digit whole numbers and moreover, to think about additional methods or procedures to get answers, which is major features of PWC tasks.

As illustrated in 〈Table 1〉, 39 percent of instructional tasks analyzed in the 7 th curriculum are low-level, specifically, procedures without connections tasks that are algorithmic and focused on producing correct answers rather than developing mathematical conceptual understanding. Those PNC tasks made no connections to the concepts or meaning that underlie the procedures and required explanations focusing only on describing the procedure used. For example, an instructional task provided story problems in real-life situations as follows: 
- Empty bottles were collected in an elementary school. 427 bottles were collected on the first day and 394 on the second day. How many were collected all together?

- A farm harvested 827 melons last year. 186 more melons are produced this year than last year. How many melons are produced this year?

- A shipyard constructed 145 ships last year and 279 this year. How many ships are made for the two years? (Ministry of Education, 2001a, p. 21)

However, the task called for the algorithm that was presented in prior instruction and what the students must do was clear from the task. Further, the task had no connection to the concepts or meaning of the operation. Thus, the task implicitly suggested using the procedure learned from prior instruction on subtraction of two 3-digit numbers, which is repeated many times as follows:

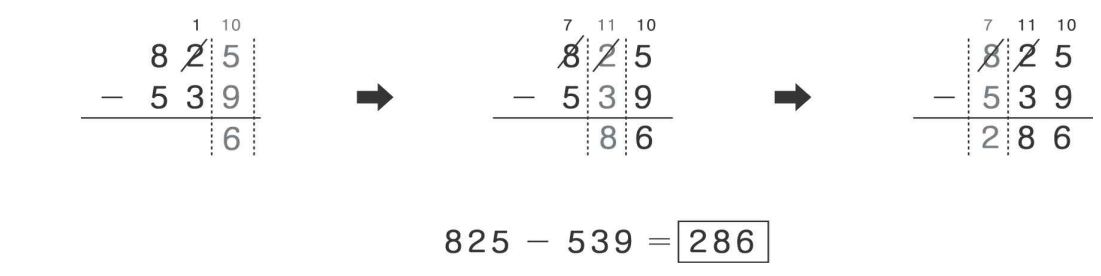

[Figure 3) A suggested method in subtracting 3-digit numbers (Ministry of Education of Korea, 2001b, p. 6)

Likewise, the instructional tasks in the curriculum material of 2007 Curriculum Amendment were comprised of more PNC tasks (9 out of 14 tasks) than PWC tasks (5 out 14 tasks) as revealed in $\langle$ Table 1$\rangle$. For example, a task in the textbook suggested third graders to compute 421 - 287 vertically and horizontally by estimation and paper-and-pencil and with base-ten blocks to check their answers. The task required students to use procedures that were suggested in the prior task by using mental estimation with hundreds- and tens-digit numbers. That is, this task seemed to focus on the use of mental estimation procedurally in adding two whole numbers and thus, give attention to correct answers rather than developing understanding. The students with the instructional tasks can complete without understanding by the procedures of mental estimation method proposed by the task. Consequently, it requires limited cognitive effort to complete successfully. The students would be able to compute the given problem procedurally regardless of their conceptual understanding of subtraction.

Second, the findings from the analysis of teachers' material in terms of whether the curriculum designers make their rationales for a particular activity or task visible to the reader reveal that 9 percent ( 2 out of 23 tasks) of the 7th curriculum were judged to be transparent and 14 percent 
( 2 out of 14 tasks) of 2007 Amendment curriculum to be transparent. Instead of describing why a certain activity or problem is suggested in order to help third graders understand whole numbers and operations of addition and subtraction and how such activity or problem is important and worthwhile to learn the concept, the Teacher's Guides from the both curricula explain the steps and procedures to follow without providing any information and explanations for their decisions on the problem selection for students. The explanations were just a replication of the procedures suggested in a form of words and solutions for problems. The Teacher's Guides, for example, portrays a method for subtracting 839 from 1325 as shown in (Figure 4):

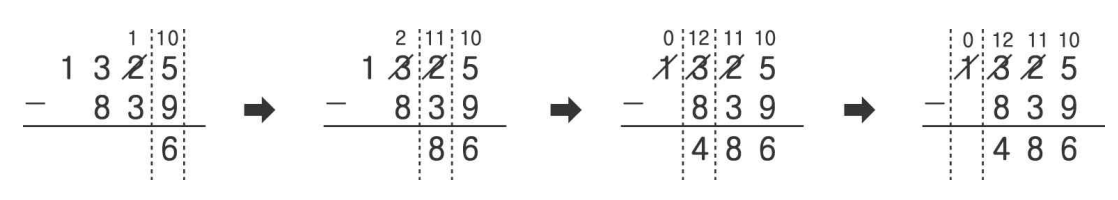

[Figure 4) Subtracting 839 from 1325

(Ministry of Education of Korea, 2001d, p. 75)

[Figure 4] is a suggested method in the textbook. Below (Figure 4), it says in the Teacher's Guides that:

1. Borrow 10 from 2 in tens digit and subtract 9 from 15 . Then $15-9=6$; write 6 in ones digit.

2. Borrow 100 from hundreds digit, which results in 11 in the digit. Then $11-3=8$; write 8 in tens digit.

3. Borrow 1000 from thousands digit, which results in 12 in the digit. Then $12-8=4$; write 4 in hundreds digit.

4. There is 0 in thousands digit; write nothing. (Ministry of Education of Korea, 2001d, p. 75)

The description does not involve any background information of the particular algorithm in subtraction. In addition, it does not provide any rationales of why the traditional strategy suggested by the task among other strategies should be taught and emphasized repeatedly throughout the tasks in the textbook. The suggested algorithm of lining up numbers and working from ones digit is not the only method for solving addition and subtraction problems. However, there were no explanations on why this particular strategy is important for students in third grade to understand the concept of subtraction and to develop the computational skills in adding and subtracting whole numbers. 
Finally, the findings on whether the teachers' materials help teachers anticipate students' responses suggest that only 4 percent ( 1 out of 23 tasks) of the 7th curriculum and 36 percent (5 out of 14 tasks) of 2007 curriculum were judged as such. Nearly all the lessons in the 7th curriculum did not provide any meaningful information about students' mathematical thinking that includes possible students' responses, examples of students' actual work for the concept, students' difficulties, errors, or confusions with the concept, possible students' strategies for solving addition and subtraction problems, or explanations of how elementary students might make sense of addition and subtraction with whole numbers.

The only case in the 7th Curriculum that was judged to help teachers anticipate students' responses explained that "With story problems involving two numbers, students tend to use only one operation that they are learning, not thinking of selecting an appropriate operation" (Ministry of Education of Korea, 2001c, p. 104). In addition, the Teacher's Guides present possible questions to ask students in performing the task:

- What are you trying to figure out?

- What is given in the problem?

- Is there an unnecessary number to solve the problem?

- Make a number sentence and use it in your computation.

- Check your computation if it is correctly done.

- State your answer. (Ministry of Education of Korea, 2001c, p. 104)

The possible questions presented, however, do not pertain to the teaching of this particular mathematical idea. Rather, the questions could be used at any time for checking problem solving steps to get correct answers, neither for the specific mathematical task nor for the conceptual understanding of numbers and operations.

The Teacher's Guides of 2007 curriculum were judged as 36 percent of lessons would help the teachers anticipate student response. The anticipating examples provided in the material, however, seemed limited in that possible student response was very general and no actual students' work or thinking processes were provided. For instance, possible strategies or responses for solving addition and subtraction problems were presented. On the other hand, the same information was repeated for a similar task: "According to research, most elementary students prefer to use this particular mental estimation strategy [suggested by a task]" (Ministry of Education, Science and Technology, 2010b, p. 133).

In addition, the teachers' materials did not contain any information about elementary students' 
difficulties in learning and understanding the concept of addition and subtraction with whole numbers, and computation by lining up the numbers by their relative digit, which is not natural. Moreover, no cues of expected students' reactions including confusions, misconceptions, common errors, etc. in the Teacher's Guides in order to help teachers teach for understanding.

\section{Discussion}

This study examined elementary mathematics curriculum materials from teachers' perspectives. In particular, the topic of addition and subtraction with whole numbers for third graders was selected and analyzed in terms of cognitive demand on instructional tasks for students. Also, this study explored teacher's materials with regard to whether the materials provide explanations to make the curriculum material designers' rationales for particular tasks visible to teachers. Finally, the teacher materials were scrutinized with respect to whether they help teachers anticipate students' responses.

The findings from the analyses, first, suggest that 61 percent of instructional tasks in the 7th curriculum and 36 percent in 2007 Amendment curriculum are procedures with connections (PWC) in terms of cognitive demand of the tasks. Although PWC tasks are considered high-level cognitive demands, there is no task at the doing mathematics level, which is the other task related to high-level cognitive demand. This particular topic of addition and subtraction with 3- or 4-digit whole numbers in grade 3 overall consists of procedures with connections tasks, which might result from the orientation that the importance of acquisition of skills and algorithms in the elementary school. This orientation, however, does not fully manifest the reform ideas in the mathematics curriculum materials. Thus, it might be natural to repeat practices with procedures without connection (PNC) tasks to reinforce the use of procedures in many different situations, but not significantly different in terms of mathematical structure, the structures of addition and subtraction such as result unknown, change unknown, start unknown, and part-whole, and mathematical operations of addition and subtraction at the same time. In addition, the both kinds of curricula organize addition and subtraction separately; there is a sequential step, addition followed by subtraction. In contrast, reform-oriented curriculum materials such as Everyday Mathematics and Investigations in the U.S. tend to not only mention all the problem structures of addition and subtraction, but also impart addition and subtraction together, not separately 
throughout the curriculum materials. In particular, Investigations suggested an activity for third graders to develop strategies to solve addition and subtraction problems and be able to relate standard addition and subtraction notation to comparison situations through a following story problem: "Let's say I grabbed 189 beans with my right hand and 150 beans with my left hand. What's the difference between the number of beans in my two hands?" (Combining and Comparing, Teacher's Guides, 1998, p. 48). It is suggested that:

Ask students to work on this problem for a few minutes and to write down their strategy for solving it. They may work with a partner if they wish. When students are satisfied with their solutions, have a few of them share their strategies. (Combining and Comparing, Teacher's Guides, 1998, p. 49).

As you work with all of the problems in this unit, encourage the flexible use of addition and subtraction. Ultimately, we hope students will see not only that both processes work, but also that these processes are quite related and are, in fact, the inverse of each other. Encourage students to articulate their ideas about adding, subtracting, and the relationship between them (Combining and Comparing, Teacher's Guides, 1998, p. 52).

The matter of transparency and anticipation visible in the Teacher's Guides should be related to the issues of cognitive demand of instructional tasks. Instructional tasks are focused not on the development of mathematical conceptual understanding and ultimately mathematical power such as mathematical problem solving and reasoning skills, but on the development of skillful performance in the computation of addition and subtraction. In other words, procedures with connection tasks emphasize the use of procedural knowledge in a meaningful context, but those tasks do not encourage students to explore mathematical ideas and structures through more various methods to tackle mathematical tasks.

The findings also suggest that the Teacher's Guides seem not transparent and to not help teachers anticipate students' responses in teaching addition and subtraction with whole numbers. The teachers' materials hardly provide possible questions to ask students to promote conceptual understanding. Even when possible questions were presented in the Teachers' Guides, such questions are not specific to the concept or ideas of mathematics. Further, those questions do not seem to promote mathematical thinking. NCTM (1991) suggests a series of questions to ask students in order to develop reasoning skills and problem solving, away from merely using procedures, which would be more helpful, as follows: 
How did you reach that conclusion?

Why do you think that?

Why is that true?

Is that true for all cases?

Can you think of a counterexample?

What assumptions are you making?

What is alike and what is different about your method of solution and other's? (NCTM,

1991, selected from pp. 3-4)

The Teacher's Guides of the 7th and 2007 Amendment curricula do not explain how teachers support their students to develop mathematical proficiency in addition and subtraction with particular instruction tasks. The purpose of teaching mathematics is to develop mathematical proficiency consisting of conceptual understanding of mathematical concepts, operations and relations, procedural fluency in solving problems, strategic competence in solving mathematical problems, and adaptive reasoning that is based on logical thinking, explanation, and justification (NRC, 2001). To successfully achieve the goal, curriculum developers should "speak to teachers" (Remillard, 2000) by making rationales for their decisions. For instance, the Teacher's Guides could afford explanations of why third graders need many opportunities to develop their understanding of story problems and to learn ways to compute by using particular methods in computing whole numbers. When curriculum designers provide explanations or information of why the algorithm should be taught among other strategies in the computation with addition and subtraction, teachers would have more flexibility in designing their own lessons and be able to organize the ideas presented in the curriculum in productive ways (Brown, 2009). For instance, a reform-oriented elementary curriculum of the U.S. offers a story for first graders, "The other day, I was watching some birds at the park. I counted 5 on one tree branch, then 2 more birds flew over and landed on the same branch," which was an activity for making sense of combining. The Teacher's Guides of Investigations illustrates that:

First graders need many opportunities to develop their understanding of story problems and to learn ways of recording their thinking clearly. (...) Interpreting story problems that describe a sequence of actions can be challenging for first graders. In this whole-class activity, the numbers in the problems are deliberately kept small so that students can work mentally and can focus on the meaning of the story problem. (...) An important aspect of solving story problems is being able to recognize the sequence of actions in the story. Ask students to try to see the story in their minds as you tell it. Some may want to close their eyes to help them concentrate. (Investigations, Grade 1 Teacher's Guides, as quoted by Stein \& Kim, 2006, p. 20) 
If a written curriculum is to present a series of highlights then a story with the highlights should be communicated in teachers' materials. Teacher's guides must support teachers in figuring out the gaps among the highlights and how different pieces are related to each other (Ball \& Cohen, 1996; Cirillo, Drake \& Herbel-Eisenmann, 2009; Davis \& Krajcik, 2005; Remillard \& Bryans, 2004). In so doing, results from relevant research studies on students' mathematics learning ought to be connected and used in the development of mathematics curriculum (Battista \& Clements, 2000). "Teacher materials that provide developed examples of potential student responses (anticipation) and mathematical rationales (transparency) for student tasks will provide more opportunity for teacher learning" (Stein \& Kim, 2006, p. 38) to promote desired students' mathematical learning. 


\section{References}

Ball, D. L., \& Cohen, D. K. (1996). Reform by the book: What is -or might be-the role of curriculum materials in teacher learning and instructional reform? Educational Researcher, 25(9), 6-8.

Battista, M. T., \& Clements, D. H. (2000). Mathematics curriculum development as a scientific endeavor. In A. E. Kelly \& R. A. Lesh (Eds.), Handbook of research design in mathematics and science education (pp. 737-760). Mahwah, NJ: Lawrence Erlbaum.

Boston, M. D., \& Smith, M. S. (2009). Transforming secondary mathematics teaching: Increasing the cognitive demands of instructional tasks used in teachers' classrooms. Journal for Research in Mathematics Education, 40, 119-156.

Brown, M. W. (2009). The teacher-tool relationship: Theorizing the design and use of curriculum materials. In J. T. Remillard, B. A. Herbel-Eisenmann \& G. M. Lloyd (Eds.), Mathematics teachers at work Connecting curriculum materials and classroom instruction (pp. 17-36). New York: Routledge.

Cirillo, M., Drake, C., \& Herbel-Eisenmann, B. (2009). Curriculum vision and coherence: Adapting curriculum to focus on authentic mathematics. Mathematics Teacher, 103(1), 70-74.

Cohen, D. K. (1990). A revolution in one classroom: A case of Mrs. Oublier. Educational Evaluation and Policy Analysis, 12, 327-345.

Collopy, R. (2003). Curriculum materials as a professional development tool: How a mathematics textbook affected two teachers' learning. Elementary School Journal, 103, 287-311.

Davis, E. A., \& Krajcik, J. S. (2005). Designing educative curriculum materials to promote teacher learning. Educational Researcher, 34(3), 3-14.

Freeman, D. J., \& Porter, A. C. (1989). Do textbooks dictate the content of mathematics in elementary school? American Educational Research Journal, 26, 403-421.

Lloyd, G. M. (1999). Two teachers' conceptions of a reform curriculum: Implications for mathematics teacher development. Journal of Mathematics Teacher Education, 2, 227-252.

Lloyd, G. M. (2008). Curriculum use while learning to teach: One student teacher's appropriation of mathematics curriculum materials. Journal for Research in Mathematics Education, 39, 63-94.

Ministry of Education of Korea. (2001a). Mathematics 3-1. Seoul: Daehan.

Ministry of Education of Korea. (2001b). Mathematics 3-2. Seoul: Daehan. 
Ministry of Education of Korea. (2001c). Teacher's Guides of Mathematics 3-1. Seoul: Daehan. Ministry of Education of Korea. (2001d). Teacher's Guides of Mathematics 3-2. Seoul: Daehan. Ministry of Education, Science and Technology. (2010a). Mathematics 3-1. Seoul: Author.

Ministry of Education, Science and Technology. (2010b). Teacher's Guides of Mathematics 3-1. Seoul: Author.

National Council of Teachers of Mathematics. (1989). Curriculum and evaluation standards for school mathematics. Reston, VA: Author.

National Council of Teachers of Mathematics. (1991). Professional standards for teaching mathematics. Reston, VA: Author.

National Council of Teachers of Mathematics. (1995). Assessment standards for school mathematics. Reston, VA: Author.

National Council of Teachers of Mathematics. (2000). Principles and standards for school mathematics. Reston, VA: Author.

National Research Council. (2001). Adding it up: Helping children learn mathematics. J. Kilpatrick, J. Swafford, \& B. Findell (Eds.). Washington, DC: National Academy Press.

Remillard, J. T. (1999). Curriculum materials in mathematics education reform: A framework for examining teachers' curriculum development. Curriculum Inquiry, 29, 315-342.

Remillard, J. T. (2000). Can curriculum materials support teachers' learning? Two fourth-grade teachers' use of a new mathematics text. Elementary School Journal, 100, 331-350.

Remillard, J. T. (2005). Examining key concepts in research on teachers' use of mathematic curricula. Review of Educational Research, 75(2), 211-246.

Remillard, J. T., \& Bryans, M. B. (2004). Teachers' orientations toward mathematics curriculum materials: Implications for teacher learning. Journal for Research in Mathematics Education, 35, 352-388.

Son, J. W., \& Senk, S. L. (2010). How reform curricula in the USA and Korea present multiplication and division of fractions. Educational Studies in Mathematics, 74, 117-142.

Stein, M. K., Grover, B. W., \& Henningsen, M. (1996). Building student capacity for mathematical thinking and reasoning: An analysis of mathematical tasks used in reform classroom. American Educational Research Journal, 33, 455-488.

Stein, M. K. \& Kim, G. (2006). Analysis of the teacher learning demands of Everyday Mathematics and Investigations in Number, Data, and Space. Paper presented at the annual meeting of the American Educational Research Association, April 7-11, San Francisco, CA.

Stein, M. K., \& Kim, G. (2009). The role of mathematics curriculum materials in large-scale 
urban reform: An analysis of demands and opportunities for teacher learning. in J. T. Remillard, B. A. Herbel-Eisenmann \& G. M. Lloyd (Eds.), Mathematics teachers at work: Connecting curriculum materials and classroom instruction (pp. 37-55). New York: Routledge.

Stein, M. K., Kim, G., \& Seely, M. (2006). The enactment of reform mathematics curricula in urban settings: $A$ comparative analysis. Paper presented at the Annual Meeting of the American Educational Research Association, San Francisco, CA.

Stein, M. K., Remillard, J. T., \& Smith, M. S. (2007). How curriculum influences student learning. In F. K. Lester, Jr. (Ed.), Second handbook of research on mathematics teaching and learning (pp. 319-369). Charlotte, NC: Information Age.

Stein, M. K., Smith, M. S., Henningsen, M. A., \& Silver, E. A. (2000). Implementing standards-based mathematics instruction: A casebook for professional development. New York: Teachers College Press.

Tarr, J. E., Chavez, O., Reys, R. E., \& Reys, B. J. (2006). From the written to the enacted curricula: The intermediary role of middle school mathematics teachers in shaping students' opportunities to learn. School Science and Mathematics, 106, 191-201.

TERC. (1998). Investigations in number, data, and space (Combining and comparing: Addition and subtraction, Grade 3). White Plains, NY: Dale Seymour.

-논문 접수 : 2010년 4월 30일 / 수정본 접수 : 2010년 6월 7일 / 게재 승인 : 2010년 6월 17일 


\section{초 록 \\ 수학교과 교육과정도서 분석: \\ 초등 3햑년의 덧셈과 뺄셈 단원을 중심으로}

김 구 연(서강대학교 조교수)

수학교과 교육과정 도서는 학생들을 위한 교과서뿐만 아니라 교사를 위한 교사용 지도서와 교육과정 해설서가 개발되어 제공되고 있다. 교사용 지도서는 교과서에서 제시한 여러 수학 문 제와 과제들에 대한 교육과정 개발자들의 의도와 설명을 담교 있다. 따라서 그러한 교사용 자 료를 통해서 교사들은 새로운 정보를 얻을 수 있고, 각 수학 문제와 과제를 통하여 가르쳐야 할 수학적 개념과 주제들에 대한 이해를 돕기도 한다. 교사용 자료를 통한 교사 학습의 기회를 확장할 수 있기 때문이다. 이 연구에서는 7차 교육과정과 2007 개정교육과정의 주요 아이디어 를 수학수업에 구현할 수 있도록 교육과정 도서들이 교사들을 어떻게 지원하고 있는지 살펴보 고자 한다. 이 연구를 위해 수학교과 초등 3핵년의 덧셈과 뺄셈 단원을 선택하여, 학생용 교과 서와 교사용 지도서를 다음과 같은 틀에서 분석하였다. 첫째, 교과서에 제시된 수업 과제의 cognitive demand의 수준을 분석하였다. 둘째, 교육과정도서 개발자가 선택하여 제시한 수업 과제에 대한 이론적 근거와 목적이 교사용 지도서에 명확하게 나타나 있는지 분석하였다. 셋 째, 교사용 지도서에 교사가 교과서에 제시된 수업 과제로 수업을 할 때 예상되는 학생들의 반 응에 대한 정보가 포함되어 있는지를 분석하였다. 분석 결과, 7 차 교육과정의 교과서 수업 과 제의 61퍼센트, 2007 개정교육과정의 36퍼센트가 상위 수준의 수업 과제로 이루어진 것으로 나타났다. 상위 수준의 과제들도 절차적 지식의 이해를 강조한 것으로 나타났다. 한편, 교사용 지도서에 선정된 수업 과제를 통해 학생들에게 가르치고자 하는 지도서 개발자의 의도와 이론 적 근거가 명확하게 제시된 경우는 7차 교육과정은 9퍼센트, 2007 개정교육과정은 14 퍼센트 로 나타났다. 또한 예상되는 학생들의 반응에 대한 교사용 지도서에서의 정보 제공은 7 차 교육 과정에서는 거의 없는 것으로, 2007 개정교육과정에서는 36퍼센트로 나타났다.

주제어 : 수학교과 교육과정, 교과서와 교사용 지도서, 교사 학습, 교육과정 도서 분석, 인 지적 요구, 초등 3학년 덧셈과 뺄셈, 교사학습 기회 